\title{
Morphological aspects of the testes of 18 species of terrestrial of Heteroptera from Northwestern São Paulo (Brazil)
}

Mariana Oliveira Gomes ${ }^{1}$, Márcia Maria Urbanin Castanhole ${ }^{1}$, Hederson Vinicius de Souza ${ }^{1}$, Aline Sumitani Murakami', Tatiani Seni de Souza Firmino', Priscila Samara Saran ${ }^{1}$, Cecilia Artico Banho ${ }^{1}$, Leticia da Silva Monteiro ${ }^{1}$, Jocielly Cristina Pereira da Silva ${ }^{1}$ \&

\author{
Mary Massumi Itoyama ${ }^{1,2}$
}

${ }^{1}$ Laboratório de Citogenética e Molecular de Insetos, Departamento de Biologia, Instituto de Biociências, Letras e Ciências Exatas, Universidade Estadual Paulista - UNESP, Rua Cristóvão Colombo, 2265, Jardim Nazareth, CEP 15054-000, São José do Rio Preto, SP, Brasil. http://www.ibilce.unesp.br/ ${ }^{2}$ Corresponding author: Mary Massumi Itoyama, e-mail: mary@ibilce.unesp.br

GOMES, M.O., CASTANHOLE, M.M.U., SOUZA, H.V., MURAKAMI, A.S., FIRMINO, T.S.S., SARAN, P.S., BANHO, C.A., MONTEIRO, L.S., SILVA, J.C.P. \& ITOYAMA, M.M. Morphological aspects of the testes of 18 species of terrestrial of Heteroptera from Northwestern São Paulo (Brazil). Biota Neotrop. 13(3): http:// www.biotaneotropica.org.br/v13n3/en/abstract?article+bn02813032013

Abstract: The Heteroptera are known for their odour, for being pests or for being disease carriers. However, they are still not extensively studied, perhaps because they form a very large group. Therefore, with the aim of enhancing the knowledge of the morphology of the testes of this insect order, we collected and analysed 18 species of terrestrial Heteroptera from the northwestern part of São Paulo. The analysis of these species revealed some differences between the testicles of these species, including their shape (elongated, oval, round or pecten), the morphology of the testicular lobes (elongated and paired side by side or united in a single region), the colours of the peritoneal sheath that surrounds the lobes (red, orange, yellow or translucent), and the number of testicular lobes (one, two, four, five, six or seven). Because the aspects analysed were highly variable, our study suggests a need for further analysis of Heteropteran testicular morphological differences.

Keywords: testicles, peritoneal sheath, lobes.

GOMES, M.O., CASTANHOLE, M.M.U., SOUZA, H.V., MURAKAMI, A.S., FIRMINO, T.S.S., SARAN, P.S., BANHO, C.A., MONTEIRO, L.S., SILVA, J.C.P. \& ITOYAMA, M.M. Aspectos testiculares de 18 espécies terrestres de Heteroptera do Noroeste de São Paulo (Brasil). Biota Neotrop. 13(3): http://www.biotaneotropica. org.br/v13n3/pt/abstract?article+bn02813032013

Resumo: Os Heteroptera são organismos conhecidos pelo seu odor, por serem pragas ou por serem transmissores de doenças, contudo, eles ainda são pouco estudados, talvez por formarem um grupo muito grande. Portanto, com o objetivo de ampliarmos as informações dos aspectos testiculares deste grupo analisamos 18 espécies de Heteroptera terrestres pertencentes a oito famílias que foram coletadas no Noroeste Paulista. Através das análises dessas espécies foi observado diferenças testiculares quanto: a sua forma (alongadas; ovalados; forma de concha, denominada pecten; ou arredondados); a morfologia dos lobos (alongados e pareados lado a lado ou unidos em uma única região, na forma de um "ofiuroide"); às cores da bainha peritoneal (alaranjada, amarelada, avermelhada ou transparente); ao número de lobos testiculares (um, dois, quatro, cinco, seis, sete). Devido aos aspectos analisados serem muito variáveis, nosso estudo sugere um aprofundamento maior na questão que envolve as diferenças morfológicas testiculares.

Palavras-chave: testículos, bainha peritoneal, lobos. 


\section{Introduction}

The Hemiptera are distributed worldwide and represent the most diverse non-Endopterygotan orders, with more than 90.000 species in approximately 140 families. Historically, this order was divided into two suborders: Heteroptera (bugs) and Homoptera (cicadas, leafhoppers, aphids, whiteflies and coccids) (Gullan \& Cranston 2008). Currently, the Hemiptera order is divided into three suborders: Auchenorrhyncha, Heteroptera and Sternorrhyncha (Cryan \& Urban 2012).

The Heteroptera possess great variation in feeding behaviours, with the majority depending exclusively on plant sap, but with additional non-phytophagous species that are predators of fungi and other arthropods and a few species that are blood-sucking or necrophagous (Gullan \& Cranston 2008).

Because the majority of Heteroptera are phytophagous, they can directly affect humans by causing serious damage to agricultural products including fruits (oranges, cashews and tomatoes) and grains (beans, corn and soy) that are used for food or drugs and also by affecting the food chain or transmitting diseases to plants. The economic importance of various Heteroptera also includes many species that are beneficial because they consume destructive insect pests. Some species are ectoparasites of humans and domestic animals, whereas others are hosts and transmitters of serious diseases to humans (Schuh \& Slater 1995).

The suborder Heteroptera includes approximately 80 families; among these, the Alydidae, Coreidae, Corimelaenidae, Lygaeidae, Reduviidae, Rhopalidae, Scutelleridae and Tingidae have the largest amounts of terrestrial representatives in the region of São José do Rio Preto (Northwest São Paulo, Brazil).

The Alydidae insects are relatively small and are generally found across North America in foliage and flowers (Froeschner 1988). The species of the Coreidae family are widely distributed, although this species is the most abundant in tropical and subtropical regions and is physically the largest in these regions. Most of the Coreidae have unusual appearances and significant economic importance (Schuh \& Slater 1995).

The species of the Corimelaenidae family are treated by some authors as a subfamily of Cydnidae and represent approximately 200 species and nine genera that are distributed in the Western Hemisphere. They are small-to-medium-sized, dark coloured and have a developed convex scutellum covering most of the forewing with a yellowish exochorion (Grazia et al. 1999).

The representatives of the Lygaeidae family are commonly known as seed insects; therefore, these insects have long proboscises that are used to drill and inject enzymes into the seeds (Schuh \& Slater 1995).

Among the Heteroptera, the family Reduviidae is distinguished for being insectivorous, phytophagous, and hematophagous, and it is therefore of great importance for agricultural productivity and human health, as family members can transmit Chagas disease during feeding. Because they are larger in size than other insect predators, Reduviidae consumes a higher number and also a broader spectrum of prey species (Panzera et al. 1992).

The species of the Rhopalidae family are distributed worldwide; all members are phytophagous and live mainly in weeds, but some are arboreal (Schuh \& Slater 1995). The Scutelleridae family is a small family that was previously considered part of the Pentatomidae but has now been separated. Scutelleridae species size can vary from medium to large, and they have a worldwide distribution, with 80 genera and 450 species. The most notable feature of the Scutelleridae is the scutellum, which overlaps the entire abdomen, hiding their wings and giving them the appearance of a beetle. These insects feed on grasses, herbs, fruits and flowers (Papeschi \& Bressa 2006).
The Tingidae family is composed of very small insects (2-10 $\mathrm{mm}$ ) that have a reticulated surface in their wings. These insects are located on the abaxial surface of leaves, where they suck sap and cause yellowing and premature senescence, causing great damage. Each individual completes the life cycle in the same plant, sometimes within the same region. Most species produce one or two generations per year, but some species produce several generations per year. Some species hibernate as adults, while others hibernate at the egg or nymph stages (Miller 2004).

The suborder Heteroptera is extremely large, with over 40.000 described species, but this number is clearly higher because many others species have yet to be described. Despite this high number of species and their wide distribution, studies regarding these insects are still very scarce and are mainly related to aspects of testicular morphology (colour of the peritoneal sheath, the testicular shape, and number and morphology of the lobes) (Souza et al. 2007a, Souza \& Itoyama 2010).

The analyses of testes variations between different groups of Heteroptera offer indications that should help behavioural and evolutionary studies. With the aim of improving the available information concerning the morphology of this organ, we analysed 18 species of Heteroptera belonging to eight families.

\section{Material and Methods}

The present study analysed 18 species of terrestrial Heteroptera belonging to eight families: Neomegalotomus parvus (Westwood, 1842) and Stenocoris furcifera (Westwood, 1842) (Alydidae); Acanonicus hahni (Stål, 1860), Acanthocephala sp. and Anisoscelis foliacea marginella (Dallas, 1852) (Coreidae); Galgupha sidae (McAtee ; Malloch, 1933) (Corimelaenidae); Oncopeltus fasciatus (Stal, 1868), Oxycarenus hyalinipennis (Costa, 1847) and Pachybrachius bilobatus (Say, 1831) (Lygaeidae); Atopozelus opsimus (Elkins, 1954) and Doldina carinulata (Stål, 1859) (Reduviidae); Harmostes apicatus (Stål, 1860), Harmostes serratus (Fabricius, 1775), Jadera haematoloma (Herrich-Schaeffer, 1847), Jadera sanguinolenta (Fabricius, 1775) and Jadera sp. (Rhopalidae); Pachycoris torridus (Scopoli, 1772) (Scutelleridae); and Dictyla monotropidia (Stål, 1858) (Tingidae).

To characterise testicular morphology, the males were first pricked with pins through the scutellum region in Petri dishes containing paraffin. With the aid of two stylets, abdominal incisions were made, and the testes were removed. Each testes was placed on a histological slide containing one drop of saline (Demerec) for the observation of their morphology, the colour of the peritoneal sheath, the morphology of the lobes and the number of testicular lobes. The observations were performed using a Stemi DV4-Zeiss stereomicroscope.

\section{Results}

The testicles of the Heteroptera species analysed had differentshaped testes, including oval (Neomegalotomus parvus, Oncopeltus fasciatus and Pachycoris torridus) (Figure 1a), pecten (Acanonicus hahni, Acanthocephala sp. and Anisoscelis foliacea) and elongated (Stenocoris furcifera, Galgupha sidae, Oxycarenus hyalinipennis, Pachybrachius bilobatus, Harmostes serratus, Harmostes apicatus, Jadera haematoloma, Jadera sanguinolenta, Jadera sp. and Dictyla monotropidia, Atopozelus opsimus and Doldina carinulata) (Figure 1c-e) (Table 1). All the testicular lobes are morphologically elongated and paired side by side, with the exception of the Reduviidae family species, in which the lobes are stretched but united in a single region (Figure 1e) (Table 1).

The analysis of the peritoneal sheath revealed different pigmentations: yellow (Oncopeltus fasciatus and Pachybrachius 

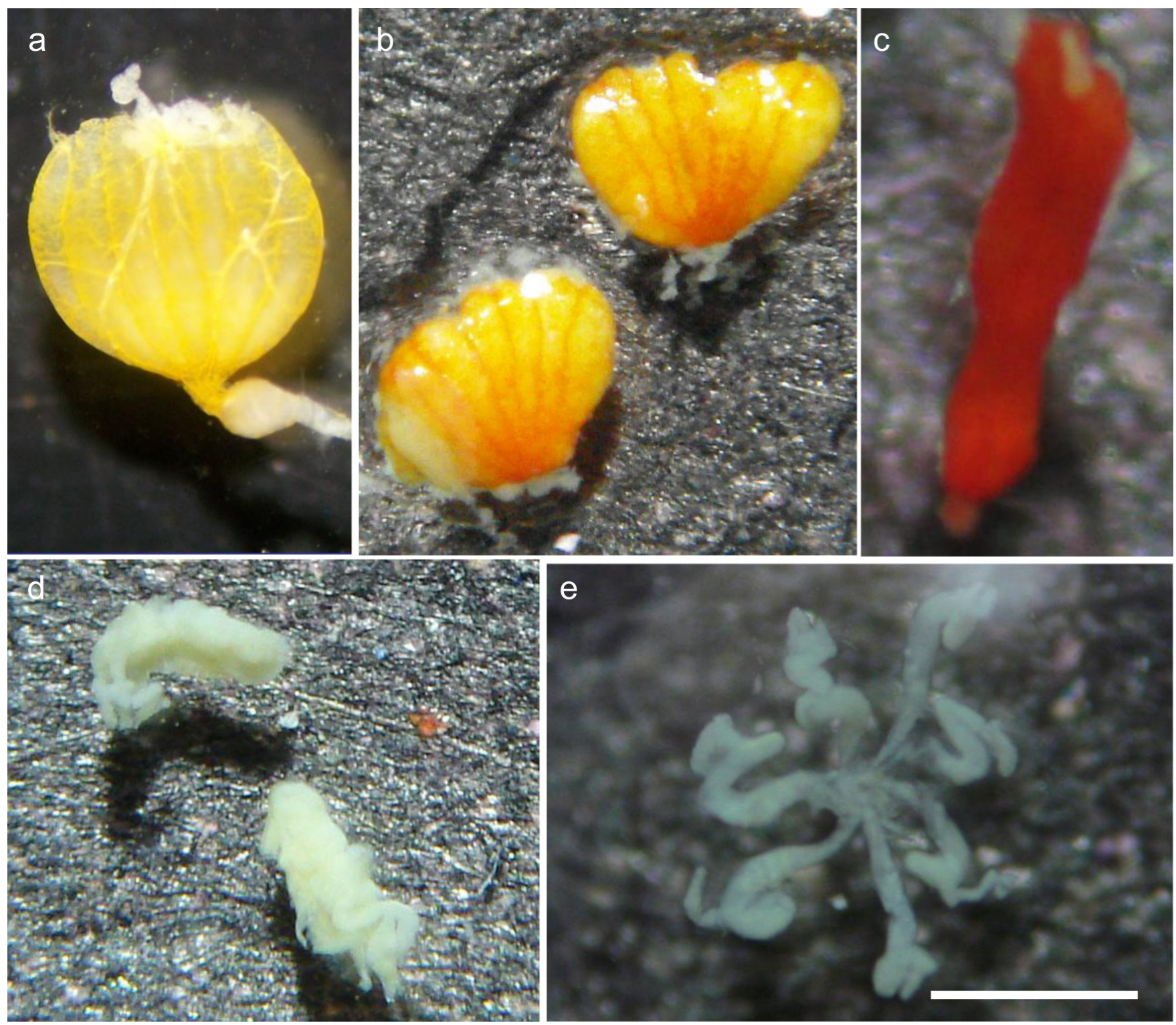

Figure 1. Testicles of terrestrial Heteroptera. a) Oval (Oncopeltus fasciatus), b) pecten-shaped (Anisoscelis foliacea marginella), and c-e) elongated (c: Oxycarenus hyalinipennis; d, e: Atopozelus opsimus) testicular lobes attached to a region. Bar: $1 \mathrm{~mm}$.

bilobatus) (Figure 1a), orange (Acanonicus hahni, Anisoscelis foliacea marginella, Galgupha sidae, Doldina carinulata, Harmostes serratus and Jadera sanguinolenta) (Figure 1b), reddish (Stenocoris furcifera, Neomegalotomus parvus, Acanthocephala sp., Oxycarenus hyalinipennis, Harmostes apicatus, Jadera haematoloma and Jadera sp.) (Figure 1c) and transparent (Atopozelus opsimus, Pachycoris torridus and Dictyla monotropidia), (Figure 1d, e) (Table 1).

Another feature observed was the number of testicular lobes. All species of the Alydidae (except Stenocoris furcifera), Coreidae, Lygaeidae (except Oxycarenus hyalinipennis), Reduviidae and Scutelleridae families had seven testicular lobes, the noted exceptions had six and two lobes, respectively. Rhopalidae had four lobes, with the exception of the Jadera sp., which had five. Corimelaenidae and Tingidae had two and one lobes, respectively (Table 1).

\section{Discussion}

Although there is not much mention in the literature concerning the morphology of the testicles of Heteroptera, the analysis of this organ has been very important because it presents very interesting features. According to the literature, the testicles of Heteroptera can be elongated, as observed in the species of the Gerridae (Castanhole et al. 2008, 2010) and Pentatomidae families (Souza et al. 2007a, Souza \& Itoyama 2010, 2011), or as observed in the present study, they can be oval (Alydidae, and Scutelleridae Lygaeidae) or pectinshaped (Coreidae). Another feature observed in our study was the morphology of the testicular lobes. The testicular lobes are elongated and separated in most of the species analysed, with the exception of the species of the Reduviidae family, in which the testicular lobes were united in a single region. With respect to these characteristics, we did not observe any relationships with the family to which they belong or feeding habits or habitat.

One feature that has been widely explored in Heteroptera is the pigmentation of the peritoneal sheath that covers the testicular lobes. For example, there are descriptions in the literature of a reddish peritoneal sheath in species of the Alydidae (Souza et al. 2009), Coreidae (Souza et al. 2007b, 2009), Lygaeidae (Souza et al. 
Table 1. Morphology of testes and testicular lobes, peritoneal sheath colour and number of testicular lobes of 18 species of Heteroptera.

\begin{tabular}{|c|c|c|c|c|c|}
\hline Family & Specie & $\begin{array}{c}\text { Morphology } \\
\text { of testes }\end{array}$ & Morphology of lobes & $\begin{array}{c}\text { Peritoneal } \\
\text { sheath }\end{array}$ & $\begin{array}{c}\begin{array}{c}\text { Number of } \\
\text { lobes }\end{array} \\
\end{array}$ \\
\hline \multirow{2}{*}{ Alydidae } & Neomegalotomus parvus (Westwood, 1842) & Oval & Elongated/Separate & Reddish & 7 \\
\hline & Stenocoris furcifera (Westwood, 1842) & Elongated & Elongated/Separate & Reddish & 6 \\
\hline \multirow{3}{*}{ Coreidae } & Acanonicus hahni (Stål, 1860) & Pecten-shaped & Elongated/Separate & Orange & 7 \\
\hline & Acantocephala sp. & Pecten-shaped & Elongated/Separate & Reddish & 7 \\
\hline & Anisoscelis foliacea marginella (Dallas, 1852) & Pecten-shaped & Elongated/Separate & Orange & 7 \\
\hline Corimelaenidae & Galgupha sidae (McAtee ; Malloch, 1933) & Elongated & Elongated/Separate & Orange & 2 \\
\hline \multirow{3}{*}{ Lygaeidae } & Oncopeltus fasciatus (Stal, 1868) & Oval & Elongated/Separate & Yellowish & 7 \\
\hline & Oxycarenus hyalinipennis (Costa, 1847) & Elongated & Elongated/Separate & Reddish & 2 \\
\hline & Pachybrachius bilobatus (Say, 1831) & Elongated & Elongated/Separate & Yellowish & 7 \\
\hline \multirow{2}{*}{ Reduviidae } & Atopozelus opsimus (Elkins, 1954) & Elongated & Attached to a region & Transparent & 7 \\
\hline & Doldina carinulata (Stål, 1859) & Elongated & Attached to a region & Orange & 7 \\
\hline \multirow{5}{*}{ Rhopalidae } & Harmostes apicatus (Stål, 1860) & Elongated & Elongated/Separate & Reddish & 4 \\
\hline & Harmostes serratus (Fabricius, 1775) & Elongated & Elongated/Separate & Orange & 4 \\
\hline & Jadera haematoloma (Herrich-Schaeffer, 1847) & Elongated & Elongated/Separate & Reddish & 4 \\
\hline & Jadera sanguinolenta (Fabricius, 1775) & Elongated & Elongated/Separate & Orange & 4 \\
\hline & Jadera sp. & & & Reddish & 5 \\
\hline Scutelleridae & Pachycoris torridus (Scopoli, 1772) & Oval & Elongated/Separate & Transparent & 7 \\
\hline Tingidae & Dictyla monotropidia (Stål, 1858) & Elongated & Elongated & Transparent & 1 \\
\hline
\end{tabular}

2007c), Pentatomidae (Souza et al. 2007a, 2008) and Rhopalidae (Souza et al. 2009) families and yellowish or transparent sheaths some species of the Coreidae (Souza et al. 2007b) and Gerridae families (Castanhole et al. 2008). Testicles with two membranes of the same pigmentation (yellowish) or different pigmentations (yellowish external and reddish internal) can also be observed, as in species of the Pentatomidae family (Souza \& Itoyama 2011). Therefore, there is no standard with which we can relate the colour of the sheath to the family. However, to date, all aquatic insects observed had a transparent sheath (Castanhole et al. 2008, 2010). The terrestrial species analysed in this study confirm this hypothesis because species of the same family had sheaths of different colours, although there were few species analysed.

The testicles of Heteroptera are formed by varying numbers of lobes. Seven lobes have been described in species of the Alydidae (Souza et al. 2009); Coreidae (Souza et al. 2007b, 2009); Pentatomidae (Souza \& Itoyama 2011) and Rhopalidae families (Souza et al. 2009); six lobes in species of the Pentatomidae family (Souza et al. 2007a, Souza \& Itoyama 2010, 2011), five lobes in the Alydidae family (Souza et al. 2009), four lobes in species of the Pentatomidae (Souza et al. 2008, Souza \& Itoyama 2011) and Coreidae families (Souza et al. 2007b), three lobes in species of the Pentatomidae family (Souza et al. 2008, Souza \& Itoyama 2011) and two lobes in the Gerridae family (Castanhole et al. 2008, 2010). From our results, we can note that the number of testicular lobes do not present a pattern within the families because the two Alydidae species analysed had different numbers of lobes (six and seven), although seven lobes were also found by Souza et al. (2009). With regard to the Coreidae family, most species described in the literature and all species analysed in this study had seven testicular lobes. The lobe count results for the Corimelaenidae (two), Lygaeidae (two, seven), Reduviidae (seven), Scutelleridae (seven) and Tingidae (one) families represent the first analysis of lobe number in these families.

As the aspects analysed were variable, we suggest that Heteroptera require further morphological study to define the characteristics of the ancestral species with respect to the colour of the peritoneal sheath and the number of testicular lobes, the features that were more variable among the species analysed.

\section{Acknowledgements}

This work was performed with the assistance of FAPESP, CAPES, CNPq and FUNDUNESP for financial support and Dr. Luis Antônio Alves Costa, University of Rio de Janeiro, RJ; Dr. Jose Antonio Marin Fernandes, University Federal of Pará, PA; and Dr. Helcio Gil Santana, Instituto Oswaldo Cruz, Rio de Janeiro for the identification of insects.

\section{References}

CASTANHOLE, M.M.U., PEREIRA, L.L.V., SOUZA, H.V., BICUDO, H.E.M.C., COSTA, L.A.A. \& M.M. ITOYAMA. 2008. Heteropicnotic chromatin and nucleolar activity in meiosis and spermiogenesis of Limnogonus aduncus (Heteroptera, Gerridae): a stained nucleolar organizing region that can serve as a model for studying chromosome behavior. Genet. Mol. Res. 7(4):1398-1407. PMid:19224457. http:// dx.doi.org/10.4238/vol7-4gmr527

CASTANHOLE, M.M.U., PEREIRA, L.L.V., SOUZA H.V. \& ITOYAMA M.M. 2010. Spermatogenesis and karyotypes of three species of water striders (Gerridae, Heteroptera). Genet. Mol. Res. 9(3):1343-1356. PMid:20645259. http://dx.doi.org/10.4238/vol9-3gmr841

CRYAN, J.R . \& URBAN, J.M. 2012. Higher-level phylogeny of the insect order Hemiptera: is Auchenorrhyncha really paraphyletic? Syst. Entomol. 37:7-21. http://dx.doi.org/10.1111/j.1365-3113.2011.00611.x

FROESCHNER, R.C. 1988. Family Alydidae Amyot and Serville, 1843. In Catalog of the Heteroptera, or True Bugs, of Canada and the Continetal United States (Henry, T.J. \& R.C. Froeschner, eds.). London, p.4-11.

GRAZIA, J., FORTES, N.D.F. \& CAMPOS, L. A. 1999. Pentatomoidea. In Biodiversidade do Estado de São Paulo, Brasil: síntese do conhecimento ao final do século XX, 5: invertebrados terrestres (C.A. Joly \& C.E.M. Bicudo, org.). São Paulo, v.5, p.101-11.

GULLAN, P.J. \& CRANSTON, P.S. 2008. Os insetos: um resumo de entomologia. 3rd ed. Roca, São Paulo.

MILLER, L.T. 2004. Lace bugs (Hemíptera: Tingidae). In: Enciclopedia of Entomology (J.L. Capinera, ed.). v. 2, p.1238-1241. http://dx.doi. org/10.1007/0-306-48380-7_2302 
PANZERA, F., AlVAREZ, F., SANCHEZ-RUfAS, J., PEREZ, R., SUJA, J.A., SCOVORTZOFF, E., DUJARDIN, J.P., ESTRAMIL, E. \& SALVATILLAR, R. 1992. C- heterochromatin polymorphism in holocentric chromosomes of Triatoma infestans (Hemiptera - Reduviidae). Genome. 35:1068-1074. http://dx.doi.org/10.1139/g92-164

PAPESCHI, A.G. \& BRESSA, M.J. 2006. Evolutionary cytogenetics in Heteroptera. J. Biol. Res. 5:3-21.

SCHUH, T.T. \& SLATER, J.A. 1995. The bugs of the world (Hemiptera: Heteroptera): Classification and natural history, Cornell University Press.

SOUZA, H.V., BICUDO, H.E.M.C., COSTA, L.A.A. \& ITOYAMA, M.M 2007a. A study of meiosis and spermatogenesis in different testicular lobes of Antiteuchus tripterus (Heteroptera: Pentatomidae). Eur. J. Entomol. 104:353-362.

SOUZA, H.V., ARAKAKI, R.L.M., DIAS, L.N., MURAKAMI, A.S., COSTA, L.A.A., BICUDO, H.E.M.C. \& ITOYAMA, M.M. 2007b. Cytogenetical aspects of testicular cells in economically important species of Coreidae family (Heteroptera). Cytologia. 72:49-56. http://dx.doi.org/10.1508/ cytologia. 72.49
SOUZA, H.V., BICUDO, H.E.M.C. \& ITOYAMA, M.M. 2007c. Study of chromosomal and nucleolar aspects in testes of Nysius californicus (Heteroptera: Lygaeidae). Genet. Mol. Res. 6:33-40. PMid:17299894.

SOUZA, H.V., CASTANHOLE, M.M.U., BICUDO, H.E.M.C., COSTA, L.A.A. \& ITOYAMA, M.M. 2008. Morphological patterns of the heteropycnotic chromatin and nucleolar material in meiosis and spermiogenesis of some Pentatomidae (Heteroptera). Genet. Mol. Res. 31:686-691.

SOUZA, H.V., SOUZA, F.B., MARUYAMA, S.R.C, CASTANHOLE, M.M.U \& ITOYAMA, M.M. 2009. Meiosis, spermatogenesis and nucleolar behavior in the seminiferous tubules of Alydidae, Coreidae and Rhopalidae (Heteroptera) species. Genet. Mol. Res. 8(4):1383-1396. PMid:19937583. http://dx.doi.org/10.4238/vol8-4gmr672

SOUZA, H.V. \& ITOYAMA M.M. 2010. Comparative Study of Spermatogenesis and Nucleolar Behavior in Testicular Lobes of Euschistus heros (Heteroptera: Pentatomidae). Psyche: J Entomol. 2010:10. http://dx.doi.org/10.1155/2010/428673

SOUZA, H.V. \& ITOYAMA, M.M. 2011. Comparative analysis of heteropyknotic chromatin and silver-stained material in Platycarenus umbractulatus (Pentatomidae: Discocephalinae). Inv. Reprod. Devel. 55(2):65-72. http://dx.doi.org/10.1080/07924259.2010.548637

Received 08/20/2012

Revised 08/11/2013

Accepted 08/30/2013 